\title{
The Cotton Industry in Germany
}

\author{
By W. F. Bruck, Рh.D. \\ Professor of Political Economy, University of Giessen, Giessen, Germany \\ Translated by George F. Cole, A.M., Instructor in French, University of Pennsylvania
}

$\mathrm{T}$ HE war, with all its consequences, was not without effect upon the German cotton industry. The first impressions after the collapse were those of a crushing chaos for the German folk, both politically and economically. So, too, there was great skepticism as to the future of this branch of industry. Today, two years after the fateful armistice, the situation has become somewhat consolidated, and our economic life again travels its wonted course. As after a long illness, there are still occasional reactions and convulsions, which express themselves in labor-unrest and industrial disturbances; but life in general, both in city and in country, has gradually become as peaceful as before the war. Even the train service is again punctual to the minute.

Let us first consider the changes from prewar conditions: The cotton industry no longer manufactures on the former scale. The labor day has been shortened, factories work only to a part of their capacity, exports have decreased, and, for our own people, the textile wares produced have become too dear. Slowly the industry has almost entirely freed itself from the forced economy of war times, which was necessary even after the end of the contest, and has struggled through to free economic conditions. The transition was difficult and was burdened with complexity, because the supplies of confiscated spinning materials and yarns were still being sold at government-controlled prices, while at the same time the newly imported raw and partially manufactured materials had to be relieved of the government price control. Thus, for a certain time, governmentally-fixed and free prices existed side by side. In the first half of the year 1919, the then existing government order concerning bills of exchange and the embargo on imports were both great hindrances to the entrance of raw cotton and cotton yarns. In August, 1919, the order was rescinded, and complete freedom of entry for textile raw materials was also legally established.

Let us examine the causes of these changes: The industry has even lost so important a producing region as Alsace-Lorraine, which manufactured from one-sixth to one-seventh of our total cotton output. This means the loss of nearly two million spindles and forty-five thousand looms, accompanied, to be sure, by the loss of the cotton-consuming population of this district. And with its spinning and weaving, Alsace-Lorraine was especially famed for its specialities in finishing and preparing for the market; notably, also, for the printing of artistic patterns, as well as for its knitting work, laces, and other branches of theindustry, such as the manufacture of good products of the spindle and of the loom, good textures, good veilings, etc., while the region was likewise famed in bleachery. Transformations seem necessary to compensate in the rest of Germany for this loss. Already the further refinement of weaves prepared 
in Germany has begun in the now French Alsace-Lorraine.

Of especial weight for the present activity of the industry is the state of foreign exchange. With the end of the blockade the German manufacturer and dealer could once again buy from foreign countries and bring in his raw materials. To this end he would buy dollars for German bank notes. But the progressing fall in the value of the mark created for this method of buying almost insurmountable difficulties. Neither the German manufacturer nor his banker had at his disposal the necessary means, nor was the demand for goods among the great masses of the population sufficient to cause them to pay the high prices demanded for such expensivelyproduced textiles.

It is to be noted that, in the great majority of cases, shipping on consignment was the means by which the manufacturer was enabled to obtain his raw materials; for in this way there was afforded him a longer period in which to make ready to pay, and he could live, so to say, from hand to mouth.

Whereas previously one hundred bales of raw cotton of average American quality had cost from twenty to twenty-two thousand marks, from the summer of 1919 to the summer of 1920 they cost from forty to one hundred times that sum. Under such price conditions, the average cotton factory required from about one hundred to one hundred fifty millions of marks, merely for its supplies of raw materials.

Let it be borne in mind that prices for raw cotton in the producing countries have, as compared with those of prewar days, at least doubled or trebled, and that at the same time, that is to say, from the beginning of the year 1919 to the middle of the year 1920 , the value of the German mark has varied from one-half to one-twentyfifth of par. The tremendous incidental risks involved in this fact have meant a considerable impairment in the industry. Under such circumstances, even works with the largest capital had to let a part of their machines lie idle.

The manufacturing companies have almost all increased many-fold their capital stock, and the banks have likewise raised their credit advances to the spinneries by fifty to one hundred per cent. In view of these conditions and of the shortening of the working day from ten to eight hours, the spinneries can often obtain barely bank credits enough to enable them to operate at twenty-five to thirty per cent of their capacity. True, most of the spinners, weavers and knitters work the whole week through, but on the average they operate only from thirty to forty per cent of their spindles, looms, etc., and a larger percentage in only a very few especially favored cases. While before the war the spinners received for a ten-hour day from three to five marks, the present-day wage on the eight-hour basis has risen from thirty to fifty marks, and is still rising. The present wages mean that the employer must pay about twelve times as much as before the war, not to mention that in the weaving industry, instead of tending three or four looms, the laborer now tends only one. To be sure, the cotton industry of Germany, in view of the slight production and the exhaustion of textile goods, has earned profits in marks which break all previous records; but in marks which in like measure have depreciated in value.

For the amelioration of the abovepictured situation of the industry, the very first requisite is to prevent the tremendous variations in the 
domestic price of cotton, which affect alike disagreeably grower, dealer and consumer. Since the variations are due only slightly to changes in the price of cotton in the lands of its production, but much more to the variation in the value of the mark relative to the dollar and the pound sterling, nothing but stabilization in the mark-value for the calculation of prices by growers and dealers can bring about the desired result. But this assumes the introduction of an official and sufficiently controlled business of dealing in foreign bills of exchange. This fact, which applies also to a large number of other branches of industry, has been sufficiently ventilated in Germany. All the controlling factors: the national bank (Reichsbank), the government (Reichsregierung) trades-unions, and private banks have united in vigorous and very promising efforts. But the chief diffculty is that nearly all foreign exchange markets refuse to recognize sales made payable in marks.

A definitive shipwreck of these efforts would perpetuate the present condition of enormous variation in the prices of the most indispensable articles of clothing for the masses, and consequent political disturbances. In the long run it is unendurable for the industrial and agricultural laborer to have to pay anywhere from 30 to 130 marks for a shirt, as was the case from the beginning of the year 1919 to the middle of the year 1920, which before the war was to be had for from 1 mark 50 to 1 mark 80 . It is to be noted that the lack of occupation and the inability to sell were alleviated by illegal importations, which of course ran counter to the government measures. By means of the "hole" in the West, to be sure, there was brought about a certain temporary relief in the shortage of certain goods; but, at the same time, many products entered which were not absolutely necessary, and which were sold as left-over goods at very high prices.

Before we proceed to point out the means which are now being used to assure to the industry the necessary raw materials and to make possible its financing, let us here call attention to its most important characteristics as to extent, locality and organization. The history of the industry shows a very rapid increase in importation, exportation and consumption. In the last three decades before the war, the importation of raw cotton had increased in extent more than two and one-half fold, and as to value almost threefold. The use of cotton per capita by the German population, which in 1840 was only 0.3 kilograms, rose by 1895 to 5 kilograms, and by 1913 to 7.2 kilograms. Before the war the industry led all others in importation, with a total of six hundred million marks. In exportation, the manufactured products from cotton also took a predominant place. In the year 1913, Germany exported over five million marks' worth of cotton yarn, thread, and cotton wares. The German industry stood third, being surpassed only by that of Great Britain and of North America. In March, 1914, in the whole world there were in operation about 144.7 millions of cotton spindles, of which Great Britain had 56.0; United States, 39.5; Germany, 11.4 millions; and the whole cotton industry, with its sister textile industries, occupied something like one-eighth part of the total German labor engaged in industry.

It is only since the eighteenth century that the German cotton industry has played an important rôle in our economic life. This is true, for instance, for the electorate of Saxony, for Silesia, for Brandenburg, for the 
Rhinelands, and for all southern Germany. At the end of the eighteenth century, with the transformation of the old hand apparatuses into machines, begins a new period, which reaches to the present time. Originally the industry had followed the course of the rivers, and long after the introduction of machinery, still occupied the old localities. All the various branches of textile technique have found their place in Germany: spinning, thread-manufacture, weaving, including the weaving of ribbons, knitting, mesh-weaving, crocheting, embroidering, lace-making, bleaching, dyeing, printing, dressing and passementerie. In the process of manufacture there are all sorts of combinations of the cotton with other materials. Down to the present time the old centers in Germany have maintained their position as the main centers of the industry. In the lead stands the region of Saxony, which makes the most highly valued of products: laces, tulle, and especially mesh, textures and knitted articles, hosiery, handkerchiefs, embroidery, and the like. In the production of mesh-work the Wurtemberg industry occupies a large place, especially in the manufacture of staple articles, but also of certain specialities. Saxony, and to a less degree Rhenish-Westphalia, are the main localities of vigogne spinning, in which the work is done by the carded-yarn method, which utilizes the shortest bits of thread (East Indian cotton, linters, cotton refuse, artificial cotton). The center of Saxony is also rich in the most diversified branches of weaving. To a considerable extent, the production of staple weaves (wash-materials, linings, fabrics for printing) are represented in South Germany. Especially the weaving of materials in the rough (unbleached, unmilled, etc.) has reached a high state of development in the last few years. Weaving in different colors has had to contend in its development with great difficulties, in consequence of the increase of a certain degree of prosperity, which, even in the case of the rural population and the common laborer, has driven out variegated bed-sheetings and table-cloths, and caused a general introduction of white underclothing where formerly the colored flannel shirt was universally worn. A large number of special weaving industries are still scattered over the above-mentioned centers, and also in Saxony and the Rhinelands (Elberfeld, Barmen) and Silesia.

On the whole, the picture shows, within the groups of the cotton industry, a great diversity which has historical causes; for the industry developed from making articles by hand at home, a custom which, save in the northeast, obtained in nearly the whole kingdom. The transition to machinemade goods (wholesale manufacturing) had its point of departure in the same localities, as a development of home-made production. The skilled labor already at hand was taken over for the wholesale, or machine industry. It is difficult to characterize uniform types of the forms of the industry, or even to estimate them critically in comparison with those of other lands; for the purpose of such a characterization, the circumstances in most of the producing lands are too varied. The spinning industry with its some three hundred enterprises, is carried on largely by mass production, whereas the weaving industry is still found in all stages of development. For instance we find in Silesia and in the Erzgebirge, and in the Saxon and Bavarian dependencies, hand-weavers, and yet we also find machine production, to the point of specialized wholesale manufacture, 
occupying thousands of modern machines and laborers. Unquestionably, the industrial methods that are to be found in England afford her textile industry special advantages, and with them, very great economic superiority. Precisely branches like that of the spinning of the finer grades were there better able to be developed. In general it may be said that the industry of England is more highly specialized than is that of Germany, a consequence of various conditions not found in Germany, of which we shall treat more fully. In the foreground in Germany is the mixed, or so-called spin-weaving industry, which has a very special significance: out of eleven and one-half millions of spindles it has $4,800,000$; and out of 280,000 cotton-spinning looms it has 116,000. The tendency toward a further development of this combined form of industry is very evident. It does not admit of the thorough-going specialization which we mentioned as obtaining in the case of England; for the conditions in Germany were too varied as compared with those of England, in the matter of locality, water-power, cheap motor-power, the labor situation, and other factors which individually influence the cost of production. This is indicated by the above-mentioned example of the finer grades of spinning. The English works uniformly show lower costs for the plant. Besides this fact, Germany brought from England most of her spinning machinery. The mere installation of a spindle without the building, freight, customs-duties, packing and setting up the machinery, make the total cost about thirty per cent higher than in England. The costs of the plant were increased by the necessity of setting up contrivances for the moistening of the air, which the ocean climate of England renders unnecessary.

Moreover, in England all the necessary industries are united within a small district. The larger part of the cotton industry lies within thirty miles of Manchester. The not-distant coal mines afford cheap heating material, and the nearness of machine factories cheapens the installation and repair of machinery. The proximity of oceanharbors and of ship-canals makes it unnecessary to keep on hand supplies of raw material, with the incidental high insurance costs, while, at the same time, the English manufacturers have to bear no heavy overland freightcharges such as we bear in Germany. Again, specialization in spinning, which has become established during the last decade, has led to an increased productivity of labor. Such thorough specialization as characterizes the English industry has, for the reasons given, not been able to take foothold to a like extent in Germany. All the more highly, therefore, must we value the beginnings that have taken place thus far in the field of fine spinning.

Aside from the official returns on production, which stretch over a period of only three or four years, there are no statistics in terms of the various standard grades: only rough estimates are at hand. It may be assumed that at the beginning of the war about four hundred thousand tons of cotton, not counting refuse, linters, etc., were consumed in Germany itself, while over seventy thousand tons were to be found in export factories. Quite roughly, we may take the number twenty-six as the average number for the German spinning production. A fifteenth part of the German production may well have reached the higher groups, from forty-seven to over one hundred. Syndicates (cartels) and agreements were only slightly devel- 
oped: they came with the last stages of production, as for instance, in the general wage schedule, and in the case of isolated highly specialized products. It must be mentioned that in the other great industries before the war much better conditions existed; that for instance in mining and the ironforging industries understandings had to be brought about only between some few industrial leaders, whereas, in the textile industry, the number of the separate branches reached to one hundred, and the number of the legally independent interested individuals reached to the thousands.

Precisely the gains of war time, especially in the field of organization, were well adapted to give to the whole industry a different stamp in the direction of greater economy in the utilization of the means of production, and in financing.

We have already made clear the causes which led, after the war, to a certain crisis in the industry. We must now point out the way which, up to this time, has been taken toward a return to normal conditions. The first result of our considerations must be that the German cotton industry is such a notable factor in world economy that it may not be ignored. The two million bales annually manufactured make it, even - for lands that produce the raw material, like the United States, of the very highest importance; and foreign industries, even with the greatest efforts, would not be able to set up, for the sake of competition, even a part of the textile machines which are on hand in Germany.

Further, the high quality of the German laborer plays a predominant part. The German laborer has shown his superiority precisely in the complete finish which he is able to put upon the product. Hence, even from this point of view, our conclusion is that ways must be found again to set in motion, for the good of all, the machines of the industry. From the German point of view, it is a question of the inactivity of more than one-half of the machines, whose idleness would, in the long run, starve a million people, with all the attendant dangers of lack of work, strikes, disturbances, and the like.

On the other hand, it lies in the interest of the cotton-producing lands again to see in Germany the massproduction of which the German machines are capable; i.e., something like from one and one-half to two million bales yearly. But exact statistics furnished by the organizations of the modern industry have shown that from the first of August, 1919, to the first of August, 1920, the production was only about five thousand bales. In order to reach the former degree of productivity it will be necessary, in addition to the removal of the financial difficulties, that the most necessary material for manufacture, namely, coal, shall not be entirely taken away from the cotton industry. Danger of this is to be found in the highest degree in the agreement recently reached at the Spa conference; for the productivity of the textile industry must necessarily lag behind activities having to do with the means of sustenance, the railways, and light and power plants.

There has been no lack of efforts to help the German cotton industry to its feet by means of credit in money or materials. Long and thorough conferences on this subject between authoritative domestic interests and very well known foreign ones, including American banking institutions, have thus far shown that these efforts, so far as they envisage aid for the total German cotton industry, have been unfruitful. The firmly knit organic union neces- 
sary to such general action must fail, on account of the manifold needs of the industry, as appears from the above described historical development. On the other hand, the German manufacturer cannot assume a debt on the basis of the foreign standard of value, no matter in what form the attempt may be made; for he never knows at what rate of exchange he must cover the credit. But such knowledge is a necessary prerequisite for his price estimates. For a long time, therefore, attempts have been made, even in foreign countries, to raise the industry by means of conferences from firm to firm, and that through agreements over the so-called Lohnarbeit (wage labor). Notably at the time of the lowest level of the German mark, it seemed to foreign merchants very inviting to profit in this way by the cheap German cost of production and wages. The above-mentioned efforts, too, have met with many difficulties, all of which cannot be mentioned here. We shall indicate only the main ones. During the period that the raw material is in process of manufacture, the foreigner regularly demands to be secured for the raw material furnished; that is to say, until the finished product is delivered. If this security is to be brought about by mortgage, the deposit of valuable papers, acceptance drafts, or the like, the German borrower is thereby limited, to the extent of his obligation, in his whole credit. $\mathrm{He}$ is thus deprived of the main incentive to business, namely, saving of working capital. Another possibility would be to give, in favor of the foreign party to the contract, a prior property right in the raw materials turned over, or to the wares made from it. In accordance with existing legal provisions regarding German private rights, as is doubtless the case in all systems of jurisprudence in the civilized world, such an ownership of property can be effected only in case there be no mixture of the raw material turned over with the raw material of the manufacturer. Technical grounds connected with the business renders freedom from mixture seldom possible.

Experience and reasoning seem to show that only one way remains of helping the German cotton manufacturer in the matter of stretching his working capital and increasing his activity. That way would be as follows: the foreign interested party concludes a bargain with a German cotton factory in regard to the finishing of a definite amount of raw material at a definite price. At the same time, between the same parties, an agreement is made to the effect that the German factory shall sell to the foreign party a definite amount of the finished product to be delivered in various months. The time of delivery must be so arranged that the production of the sold finished product may be possible within the time. In both agreements there must be the provision that the debt growing out of each agreement be weighed against that flowing from the other, and in both agreements the prices are to be paid at the same rate of exchange. Even with such an agreement, to be sure, the foreign party is without security for the raw material during the time of manufacture. But it is believed that this business arrangement, if at first it be tried with only large and reliable firms and to a moderate degree, will little by little reëstablish the necessary confidence on the part of the foreign parties. Furthermore, this risk may be turned over to bankers or insurance companies on payment of a moderate premium. 